\title{
Improvements in Material Characteristics Core Centrifugally Cast Rolls
}

Tomáš Válek ${ }^{1}$, Jiří Hampl², Jakub Rušaj²

${ }^{1}$ Vítkovické Slévárny, spol. s r.o., Halasova 2904, 70602 Ostrava - Vítkovice, Czech Republic. E-mail: valek@vitkovickeslevarny.cz

${ }^{2}$ VŠB-Technical Univesity of Ostrava, Ostrava, Czech Republic, jiri.hampl@vsb.cz

The paper describes the influence of metallurgical processing on the microstructural characteristics of spheroidal graphite cast iron. The iron is used for casting the core of double layer centrifugally cast rolls. Low carbon content in the core spheroidal graphite cast iron supporting metastable solidification was eliminated by managing of metallurgical processing of spheroidal graphite cast iron. The metallurgical quality of the cast iron was controlled by using thermal analysis during all time i.e. melting furnace, through modification and inoculation. The metallurgical quality is documented by metallographic analysis, determination of surface proportion and amount of graphite on surface etched specimen. Test rolls were cast in operating conditions in roll foundry Vítkovické foundries, spol. $s$ r.o. Evaluation of melts and microstructures were made in the laboratories of the VSB-TU Ostrava.

Keywords: Centrifugally cast rolls, metallurgical quality, spheroidal graphite cast iron, inoculation

\section{Acknowledgement}

This paper was made with the support of TA CR within the project ev. no. TA04010223.

\section{References}

[1] VALEK, T., HAMPL, J. (2011). Prediction of Metallurgic Quality of ICDP Material before Tapping, Physics Procedia Volume 22 (2011), Pages 191-196, 2011 International Conference on Physics Science and Technology, doi:10.1016/j.phpro.2011.11.030

[2] HAMPL, J., VALEK, T., LICHY, P., ELBEL, T.(2014). Control of the metallurgical processing of ICDP cast irons, Materiali in tehnologije / Materials and technology 48 (2014) 5, 685-688, ISSN 1580-2949

[3] VALEK, T., ŠIMON, P., STRILKOVA, L. (2012) The Comparison of Selected Methods of Cast Iron Spheroidisation in Industrial Conditions, A R C H I V E S Of F O U N D R Y E N G I N E E R I N G, ISSN (1897 3310) Volume 12 Issue 2/2012

[4] HAMPL, J., ELBEL, T., VALEK, T. (2015) Application of thermodynamic calculation in the research of cast irons structure. Metalurgija, vol 54, No 2, pp. 323-327, 2015

[5] HAMPL, J., ELBEL, T (2009). Influence of Al and Ti on microstructure and quality of compacted graphite iron castings. Metalurgija, vol 48, No 4, pp. 243-249, 2009

[6] LICHÝ, P., BEŇO, J., CAGALA, M. (2013) Inoculant Addition Effect on Thermomechanical and Thermophysical Properties of Mg-Sr Magnesium Alloy. Manufacturing Technology, vol. 13, No 201313, pp. 64-67, ISSN 12132489, 2013

[7] VASKOVA, I. ŠEBEK, P., MULLI, I.(2013) Hardness of Ductile Cast Iron Castings and its Control in Praxis, Manufacturing Technology, vol. 13, No 201323, pp. 120-122, ISSN 1213-2489, 2013 